\title{
Down-regulation of Toll-like Receptor TLR4 Is Associated with HPV DNA Integration in Penile Carcinoma
}

\author{
MIKLOS DAMASDI ${ }^{1}$, KRISZTINA KOVACS $^{2}$, NELLI FARKAS ${ }^{3}$, FERENC JAKAB ${ }^{4}$ and GYULA KOVACS ${ }^{1,5}$ \\ ${ }^{1}$ Department of Urology, Medical School, University of Pecs, Pecs, Hungary; \\ ${ }^{2}$ Institute of Pathology, Medical School, University of Pecs, Pecs, Hungary; \\ ${ }^{3}$ Institute of Bioanalysis, Medical School, University of Pecs, Pecs, Hungary; \\ ${ }^{4}$ Institute of Biology, Medical School, University of Pecs, Pecs, Hungary; \\ ${ }^{5}$ Medical Faculty, Ruprecht-Karls-University, Heidelberg, Germany
}

\begin{abstract}
Background/Aim: Development of penile cancers is attributed to HPV-related carcinogenesis. Our aim was to analyze HPV positivity and TLR4, p16 ink4a and $p 53$ expression. Materials and Methods: HPV presence was assessed with virus-specific TaqMan PCR and HPV Genotyping Test in 31 penile cancers. Immunohistochemistry was carried out on tissue microarray. Results: TLR4 expression was detected in 4 of the $16 \mathrm{HPV}$ positive and 13 of the $15 \mathrm{HPV}$ negative tumors. We found a significant inverse correlation between HPV positivity and TLR4 expression ( $p=0.0006)$. Ten of the $16 \mathrm{HPV}$-positive but none of the $15 \mathrm{HPV}$-negative tumors expressed p16INK4a. A significant correlation was seen between $p 53$ expression and lack of HPV DNA $(p=0.0191)$ as well as between TLR4 and p53 expression $(p=0.0198)$ in penile cancers. Conclusion: Our findings suggest a protective role of TLR4 expression against HPV DNA integration and the viral and non-viral carcinogenesis of penile cancer.
\end{abstract}

Nearly half of penile cancers can be attributed to human papilloma virus (HPV)-related carcinogenesis although the percentage is varying according to geographic distribution and histological types of tumors (1). Low-risk HPV genotypes cause benign genital warts, whereas the high risk genotypes are associated with development of squamous cell carcinomas (2). In penile cancer HPV 16 and 18 are the most commonly detected HPV genotypes (3). The HPV integration into the host DNA results in overexpression of

Correspondence to: Gyula Kovacs, Department of Urology, Medical School, University of Pecs, Munkacsy M. u. 2, H-7621 Pecs, Hungary. Tel: +36 72507334, Fax: +36 72242374, e-mail: g.kovacs@gmx.de; gyula.kovacs@urz.uni-heidelberg.de

Key Words: Penile cancer, HPV, TLR4, P53, immunohistochemistry. viral oncogenes E6 and E7, which disturb cellular differentiation, proliferation and apoptosis. The viral oncogenes interact with the retinoblastoma protein $(\mathrm{pRb})$ and finally lead to accumulation of $\mathrm{p} 16^{\text {ink4a }}$ in cytoplasm and nucleus (4). E6 down-regulates the expression of transcription factor NF-kB and thus disrupts the immune response to the viral infection (5). Both E6 and E7 play role in the evasion of immune system and thus allowing the persistence of HPV in infected cells.

The host immune system has a seminal role in clearance of HPV infection (6). It was shown that HPV-related cervical cancers appear more often in immunocompromised individuals (7). Toll like receptors (TLRs) are main actors of the innate immune response against HPV (8). Human TLRs are eleven transmembrane signaling receptors with similar structures. By recognition of a foreign antigen they will be activated and via the NF-kB pathway upregulate the expression of inflammatory cytokines and innate immune system proteins (9). Therefore, a physiological TLR4 signaling has an opposite effect in immune response than E6 and E7 viral oncogenes.

Based on viral DNA analysis and immunohistochemistry, it has been suggested that penile cancer develops in two pathways: one associated with HPV integration and overexpression of $\mathrm{p} 16^{\mathrm{ink} 4 \mathrm{a}}$ and the other related to non-viral factors such as chronic inflammation, phymosis, UV-A phototherapy and lichen sclerosis and the latter express p53 but lack p16 ${ }^{\text {ink4a }}$ overexpression (10). The present report examines the HPV DNA as well as the expression of p16 $6^{\text {ink4a }}, \mathrm{p} 53$ and for the first time TLR4 with the aim to elucidate the developmental pathways in penile cancers.

\section{Patients and Methods}

Patients and tumor samples. Tissue samples of 31 penile cancers operated between 2002 and 2012 at the Department of Urology, 
University of Pecs, Hungary were processed for histological analysis. The clinical and histological data were obtained from the tumor registry of the Department of Urology (Table I). As the sample size was limited, we did not evaluate the histologic subtypes of penile cancers. The presence of nodal metastasis was confirmed by histological examination. This study was approved by the Ethic Commission of the University of Pecs.

HPV analysis. From paraffin blocks containing tumor tissues $10 \mu \mathrm{m}$ sections were dewaxed, the tissues were disintegrated using a TissueLyser (Qiagen, Biomarker Ltd., Budapest, Hungary) and the cells were digested with Proteinase-K. DNA was extracted using QIAamp DNA FFPE Tissue Kit (Qiagen, Biomarker Ltd., Budapest, Hungary) according to the manufacturer's recommendations. HPV DNA was detected by virus-specific TaqMan PCR (DIAGON Ltd., Budapest, Hungary). DNA from HPV positive cases were genotyped by LINEAR ARRAY ${ }^{\circledR}$ HPV Genotyping Test (Roche Hungary Ltd., Budapest, Hungary) as described previously (11).

Tissue microarray (TMA) and immunohistochemistry. TMAs was constructed from paraffin embedded material after marking the areas of interest on H\&E stained slides by one of the authors (GK) by using a Manual Tissue Arrayer (MTA1, Beecher Instruments, Inc., Sun Prairie, CA, USA) and $0.6 \mathrm{~mm}$ core biopsies. From each tumour at least 3 biopsies were taken. The $4 \mu \mathrm{m}$ sections of TMA placed onto FLEX IHC microscope slides (DAKO, Glostrup, Denmark) were dewaxed in xylene and rehydrated in graded ethanol. Antigen retrieval was performed by boiling the slides in $10 \mathrm{mM}$ sodium citrate buffer, pH 6.0 in 2100-Retriever (Pick-Cell Laboratories, Amsterdam, The Netherlands). Endogenous peroxidase activity and nonspecific staining were blocked by incubation with $3 \%$ hydrogen peroxide containing $1 \%$ normal horse serum for $10 \mathrm{~min}$ at room temperature. Slides were then incubated overnight at $4^{\circ} \mathrm{C}$ in a moist chamber with the anti-TLR4 rabbit antibody (NBP1-31225, Novus Biologicals, Littleton, CO, USA) at the dilution of 1:250. HRP conjugated anti-rabbit secondary antibody (MACH4 Universal HRP-Polymer, Biocare Medical, Concord, USA) was applied for $30 \mathrm{~min}$ and color was developed using AEC substrate (DAKO, Glostrup, Denmark). Tissue sections were counterstained with Mayer's hematoxylin (DAKO, Glostrup, Denmark).

TMA sections were also stained with anti-p16 rabbit monoclonal antibody (DB Biotech, Kosice, Slovak Republic) (dilution 1:100) and with anti-p53 rabbit monoclonal antibody (Clone SP5, ThermoFisher Scientific, Budapest, Hungary) (dilution 1:200) after antigen retrieval at $\mathrm{pH} 6$ and $\mathrm{pH} 9$, respectively. The immunohistochemistry was processed in a BOND-MAX Automated IHC/ISH Stainer (Leica Biosystems, BioMarker Ltd. Godollo, Hungary) and the reaction was visualized by DAB (DAKO, Glostrup, Denmark).

Slides stained with TLR4, p16 ink4a and P53 antibodies were evaluated twice by one of the authors blinded to the HPV data (GK). As the percentage of positively stained cells made up at least 80 per cent of tumor cells in all positive biopsies, we did not evaluate the number of positive cells as a parameter. We have classified the staining intensity as follows: no staining, weak, moderate or strong staining.

Statistical methods. Correlation between HPV positivity, TLR4, p53 and p16 expression was analyzed with Pearson's Chi square test. The results were considered significant if $p$-value was under 0.05 . All calculations were performed with SPSS (IBM Corporation, New York, USA, v24.0).
Table I. Pertinent pathological, virological and immunohistochemical data.

\begin{tabular}{|c|c|c|c|c|c|}
\hline Patients & TNM-G & $\begin{array}{c}\text { HPV/ } \\
\text { genotype }\end{array}$ & TLR4 & $\mathrm{p} 16^{\text {ink4a }}$ & p53 \\
\hline 1 & $\mathrm{pT} 2, \mathrm{~N} 0, \mathrm{Mx}, \mathrm{G} 3$ & Positive/16 & 0 & 1 & 1 \\
\hline 2 & $\mathrm{pT} 2, \mathrm{~N} 0, \mathrm{Mx}, \mathrm{G} 2$ & Positive/16 & 1 & 1 & 0 \\
\hline 3 & pT2,N0,Mx,G3 & Positive/16 & 0 & 1 & 0 \\
\hline 4 & $\mathrm{pT} 1, \mathrm{~N} 0, \mathrm{Mx}, \mathrm{G} 2$ & Positive/16 & 0 & 0 & 0 \\
\hline 5 & $\mathrm{pT} 2, \mathrm{~N} 0, \mathrm{Mx}, \mathrm{G} 2$ & Positive/16 & 0 & 0 & 0 \\
\hline 6 & $\mathrm{pT} 1, \mathrm{~N} 3, \mathrm{Mx}, \mathrm{G} 3$ & Positive/16 & 1 & 1 & 1 \\
\hline 7 & $\mathrm{pT} 1, \mathrm{~N} 0, \mathrm{Mx}, \mathrm{G} 1$ & Positive/16 & 0 & 1 & 1 \\
\hline 8 & $\mathrm{pT} 4, \mathrm{~N} 2, \mathrm{Mx}, \mathrm{G} 3$ & Positive/16 & 1 & 1 & 0 \\
\hline 9 & $\mathrm{pT} 4, \mathrm{~N} 2, \mathrm{Mx}, \mathrm{G} 3$ & Positive/16 & 0 & 0 & 0 \\
\hline 10 & $\mathrm{pT} 3, \mathrm{~N} 1, \mathrm{Mx}, \mathrm{G} 3$ & Positive/16 & 0 & 0 & 0 \\
\hline 11 & $\mathrm{pT} 1, \mathrm{~N} 0, \mathrm{Mx}, \mathrm{G} 3$ & Positive/59 & 1 & 1 & 1 \\
\hline 12 & cis & Positive/51,82 & 0 & 1 & 0 \\
\hline 13 & $\mathrm{pTa}, \mathrm{N} 0, \mathrm{Mx}, \mathrm{G} 1$ & Positive/82 & 0 & 0 & 0 \\
\hline 14 & $\mathrm{pT} 1, \mathrm{~N} 3, \mathrm{Mx}, \mathrm{G} 3$ & Positive/na & 0 & 1 & 1 \\
\hline 15 & $\mathrm{pT} 3, \mathrm{~N} 0, \mathrm{Mx}, \mathrm{G} 3$ & Positive/na & 0 & 0 & 0 \\
\hline 16 & $\mathrm{pT} 3, \mathrm{~N} 2, \mathrm{Mx}, \mathrm{G} 3$ & Positive/na & 0 & 1 & 0 \\
\hline 17 & $\mathrm{pT} 3, \mathrm{~N} 2, \mathrm{Mx}, \mathrm{G} 3$ & neg & 1 & 0 & 1 \\
\hline 18 & $\mathrm{pT} 2, \mathrm{~N} 3, \mathrm{M} 1, \mathrm{G} 3$ & Negative & 1 & 0 & 0 \\
\hline 19 & $\mathrm{pT} 1, \mathrm{~N} 0, \mathrm{Mx}, \mathrm{G} 1$ & Negative & 1 & 0 & 1 \\
\hline 20 & $\mathrm{pT} 2, \mathrm{~N} 2, \mathrm{Mx}, \mathrm{G} 1$ & Negative & 0 & 0 & 0 \\
\hline 21 & $\mathrm{pT} 1, \mathrm{~N} 0, \mathrm{Mx}, \mathrm{G} 1$ & Negative & 0 & 0 & 1 \\
\hline 22 & $\mathrm{pT} 3, \mathrm{~N} 2, \mathrm{Mx}, \mathrm{G} 2$ & Negative & 1 & 0 & 1 \\
\hline 23 & $\mathrm{pT} 1, \mathrm{~N} 0, \mathrm{Mx}, \mathrm{G} 1$ & Negative & 1 & 0 & 1 \\
\hline 24 & $\mathrm{pT} 1, \mathrm{~N} 2, \mathrm{Mx}, \mathrm{G} 2$ & Negative & 1 & 0 & 1 \\
\hline 25 & $\mathrm{pT} 1, \mathrm{~N} 0, \mathrm{Mx}, \mathrm{G} 3$ & Negative & 1 & 0 & 0 \\
\hline 26 & $\mathrm{pT} 2, \mathrm{~N} 2, \mathrm{Mx}, \mathrm{G} 3$ & Negative & 1 & 0 & 1 \\
\hline 27 & $\mathrm{pT} 2, \mathrm{~N} 0, \mathrm{Mx}, \mathrm{G} 2$ & Negative & 1 & 0 & 1 \\
\hline 28 & $\mathrm{pT} 1, \mathrm{~N} 0, \mathrm{Mx}, \mathrm{G} 2$ & Negative & 1 & 0 & 1 \\
\hline 29 & $\mathrm{pT} 1, \mathrm{~N} 0, \mathrm{Mx}, \mathrm{G} 1$ & Negative & 1 & 0 & 1 \\
\hline 30 & $\mathrm{pT} 1, \mathrm{~N} 0, \mathrm{Mx}, \mathrm{G} 2$ & Negative & 1 & 0 & 0 \\
\hline 31 & $\mathrm{pT} 3, \mathrm{~N} 2, \mathrm{Mx}, \mathrm{G} 3$ & Negative & 1 & 0 & 1 \\
\hline
\end{tabular}

na: Not analysed; 0: negative; 1: positive.

\section{Results}

High-risk HPV was identified in 16 of 31 primary penile cancers. The average age of patients with HPV positive tumors was 55 years (range $=44-87$ years) whereas HPV negative patients in average 66 years (range $=50-82$ years). Genotyping of HPV was available from 13 out of $16 \mathrm{HPV}$ positive cases. HPV16 was identified in 10 of 13 samples, HPV59 and HPV 82 were detected in two further cases and both HPV51 and HPV82 were detected in a single case (Table I).

A weak to moderate TLR4 expression was detected in 4 of the $16 \mathrm{HPV}$ positive cases, whereas moderate to strong immunostaining was seen in 13 out of the 15 HPV negative tumors. Pearson's Chi-square test revealed significant inverse correlation between HPV positivity and TLR4 expression 

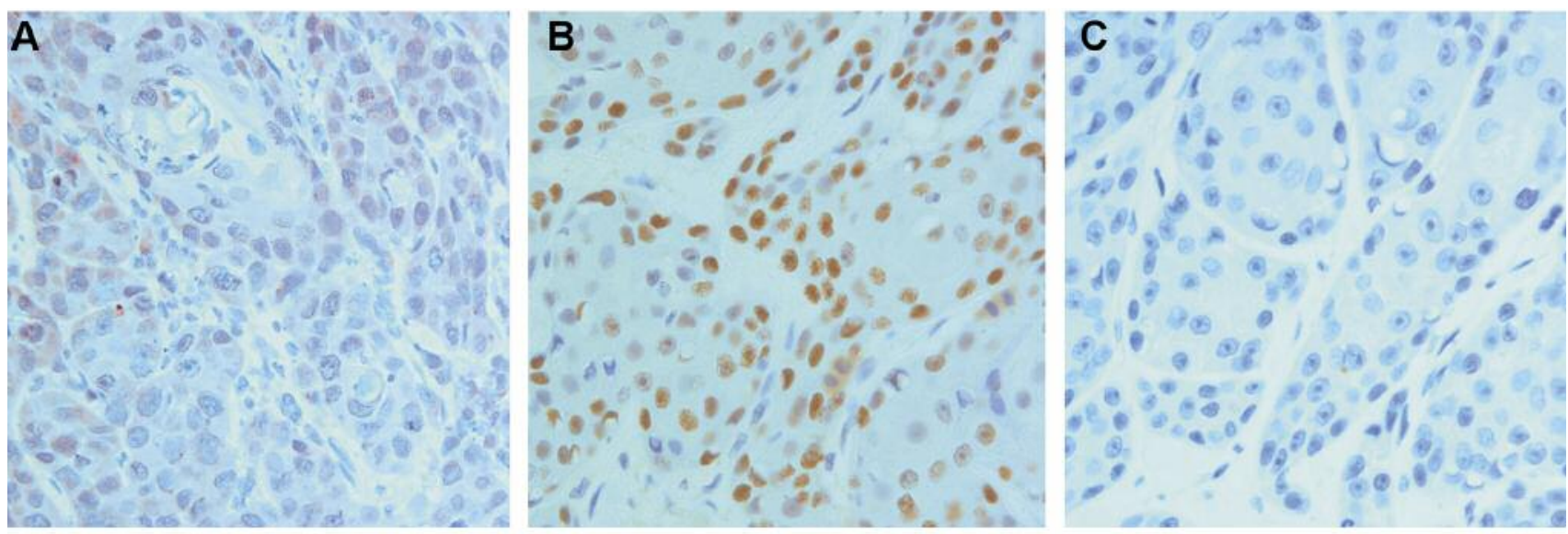

Figure 1. Immunohistochemistry of TLR4, p53 and p16ink4a in a penile cancer. A: Diffuse positive staining with TLR4. B: Moderate to strong nuclear reaction with 553 antibody. C: No staining with p16ink4a antibody.

$(p=0.0006)$. We have detected a strong cytoplasmic and occasionally nuclear staining with the $16^{\text {ink4a }}$ antibody in 10 penile cancers, all of them were positive for HPV as well. None of the HPV negative cancers showed positive staining with $\mathrm{p} 16^{\text {ink4a }}$ antibody. Pearson's Chi-square test showed a significant correlation between HPV positivity and expression of $\mathrm{p} 16^{\mathrm{ink} 4 \mathrm{a}}$ protein $(p=0.0002)$. Only 5 of the 16 HPV tumors were stained with the p53 antibody, whereas 11 of the $15 \mathrm{HPV}$-negative tumors showed positive staining $(p=0.0191)$. We found a significant correlation between TLR4 and p53 expression, 10 of the 15 HPV-negative tumors co-expressed both proteins $(p=0.0198)$. The results of immunohistochemistry are shown in Table I.

Evaluating the HPV positivity and expression of the three antibodies, we have delineated two groups of tumors with a characteristic pattern. HPV-positive group of tumors was positive for the $\mathrm{p} 16^{\mathrm{ink} 4 \mathrm{a}}$ protein, the expression of which was not detected in HPV negative cancers. The second group of penile cancers was HPV negative and expressed preferentially TLR4 and p53 proteins (Figure 1).

\section{Discussion}

Our findings support the role of HPV in the development of penile carcinomas. In HPV-induced carcinogenesis, the E7 oncogene inactivates the retinoblastoma gene product $\mathrm{pRb}$ and in turn leads to overexpression of the $\mathrm{p} 16^{\mathrm{ink} 4 \mathrm{a}}(12)$. Therefore, the HPV positivity and $\mathrm{p} 16^{\text {ink4a }}$ expression in the same tumor strongly suggest a biologically relevant infection. In our series 10 of the 31 penile cancers overexpressed $\mathrm{p} 16^{\text {ink4a }}$ and all the 10 tumors were also positive for HPV indicating the major role of HPV infection at least in these cancers.
In the vast majority of cases HPV infects transitionally skin and mucous membrane, but only few persons suffered from long term HPV infection (13). First reaction to the viral infection is the innate immune response, the adaptive immune response develops slowly (14). The efficient innate immune response depends on the host ability to recognize an invading pathogen. TLRs are pattern recognition receptors able to recognize conserved components of microbes and trigger an immune response against invading microorganisms. TLR4 is a signaling receptor for endotoxins of Gram-negative bacteria. At constitutive concentrations, the lipopolysacharide binding protein (LBP) binds bacterial lipopolysaccharide (LPS) and peptidoglycans and catalyzes their transfer via a CD14enhanced mechanism to a receptor complex including TLR-4. TLR4 can also recognize viruses, endogenous ligands such as heat shock proteins, extra cellular matrix components including fibronectin and heparin sulphate in response to tissue injury $(15,16)$. Activation of TLR4 mediated signalling leads via NFkB pathway to the release of inflammatory cytokines and innate immune system proteins of proinflammatory cytokines $(17,18)$.

We found most frequently the high-risk genotype HPV16 in penile carcinomas whereas other genotypes such as HPV51, HPV52 and HPV82 were detected only in single cases. This might be explained by the observation that HPV 16 is able to evade immune recognition by modulating TLR4 expression and therefore to persist in infected cells (19). There is evidence that HPV16 persists nearly 50-times more frequently in cervical epithelium than other HPV genotypes $(20,21)$. The TLR4 expression is decreased during progression of cervical carcinoma in situ towards invasive cancer (22). In head and neck squamous cell carcinomas TLR4 downregulation has been identified in a 
group of tumours with HPV integration (23). In our study the TLR4 immunostaining is inversely associated with HPV positivity ( $p=0.0006$ ) supporting the role of TLR4 signaling in the clearance of virus infection.

Our findings support viral and non-viral pathways of penile cancer development as suggested by other investigators $(4,10)$. The etiologic role of HPV integration and $\mathrm{p} 16^{\text {ink } 4 \mathrm{a}}$ expression as a marker of biologically active papilloma virus in penile cancer and other HPV-related cancer is well established (4). However, data on p53 expression in penile cancers are controversial. A positive correlation as well as negative or inverse correlation between HPV infection and p53 expression has been described (24, 25). We detected a significant correlation between lack of HPV integration and p53 expression as well as between p53 and TLR4 expression.

In summary, we have shown for the first time an inverse relationship between HPV infection and TLR4 expression in penile cancer. We add a new marker to the non-viral pathway and suggest that TLR4 expression marks HPV-negative tumors as p16 $6^{\text {ink4a }}$ does HPV-positive penile cancers. Our data suggest that expression of TLR4 receptor may protect from persistence of viral infection. HPV infection and its inverse association with p53 expression suggest a HPVrelated and HPV-unrelated pathogenesis of penile cancer.

\section{Conflicts of Interest}

Authors have no conflicts of interest to declare.

\section{Acknowledgements}

The present contribution is dedicated to the 650th anniversary of the foundation of the University of Pecs, Hungary.

\section{References}

1 Hakenberg OW, Comperat EM, Minhas S, Necchi A, Protzel C and Watkin N: EAU guidelines on penile cancer: 2014 update. Eur Urol 67: 142-150, 2015.

2 Munoz N, Bosch FX, De Sanjose S, Herrero R, Castellsague X, Shah KV, Snijders PJ and Meijer CJ: Epidemiological classification of human papillomavirus types associated with cervical cancer. N Eng J Med 348: 518-527, 2003.

3 Heidemen DA, Waterboer T, Pawlita M, Delis van Diemen P, Nindl I, Lejite JA, Bonfrer JM, Horenblas S, Meijer CJ and Sneijders PJ: Human papillomavirus-16 is the predominant type etiologically involved in penile squamous cell carcinoma. J Clin Oncol 25: 4550-4556, 2007.

4 Ferreux E, Lont AP, Horenblas S, Gallee MP, Raaphorst FM, von Knebel Doeberitz M, Meijer CJ and Snijders PJ: Evidence for at least three alternative mechanisms targeting the $\mathrm{p} 16^{\mathrm{INKA}} /$ cyclin $\mathrm{D} / \mathrm{Rb}$ pathway in penile carcinoma, one of which is mediated by high-risk human papillomavirus. J Pathol 201: 109-118, 2003.
5 Mantovani $\mathrm{F}$ and Banks L: The human papilloma virus E6 protein and its contribution to malignant progression. Oncogene 20: 7478-7487, 2001.

6 Stanley MA, Prett MR and Coleman N: HPV: from infection to cancer. Biochemical Society Transactions 35: 1456-1459, 2007.

7 Roden R and Wu TC: How will HPV vaccines affect cervical cancer, Nature Reviews 6: 753-763, 2006.

8 Daud II, Scott ME, Ma Y, Shiboski S, Farhat S and Moscicki AB: Association between toll-like receptors expression and human papillomavirus type 16 persistence. Int J Cancer 128: 879-886, 2011.

9 Carpenter S and O Neill LAJ: How important are Toll-like receptors for antimicrobial responses? Cellular Microbiology 9: 1891-1901, 2007.

10 Mannweiler S, Sygulla S, Winter E and Regauer S: Two major pathways of penile carcinogenesis: HPV-induced penile cancers overexpress p16 ink4a, HPV-negative cancers associated with dermatoses express p53, but lack p16 ${ }^{\text {ink4a }}$ overexpression. J Am Acad Dermatol 69: 73-81, 2013.

11 Damasdi M, Jakab F, Kovacs K, Oldal M, Kemenesi G, Szabó E, Valyi-Nagy I, Pytel A and Farkas L: Prevalence and type diversity of human papillomaviruses in penile cancers in Hungary. Pathol Oncol Res 22: 643-646, 2016.

12 Nilsson K, Svensson S and Landberg G: Retinoblastoma protein function and p16INK4a expression in actinic keratosis, squamous cell carcinoma in situ and invasive squamous cell carcinoma of the skin and links between p16INK4a expression and infiltrative behaviour. Mod Pathol 17: 1464-1474, 2004.

13 Walboomers JM, Jacobs MV, Manos MM, Bosch FX, Kummer JA, Shah KV, Snijders PJ, Peto J, Meijer CJ and Munoz N: Human papillomavirus is a necessary cause of invasive cervical cancer worldwide. J Pathol 189: 12-19, 1999.

14 Frazer IH: Interaction of human papillomaviruses with the host immune system: a well evolved relationship. Virology 384: 410414, 2009.

15 Barton GM: Viral recognation by Toll-like receptors. Semin Immunol 19: 33-40, 2007.

16 Takeda $\mathrm{K}$ and Akira S: Toll-like receptor sin innate immunity. Int Immunol 17: 1-14, 2005.

17 Faure E, Equils $\mathrm{O}$ and Sieling PA: Bacterial lipopolysacchride activates NF-kappaB through toll-like receptor 4 (TLR-4) in cultured human dermal endothelial cells. Differential expression of TLR-4 and TLR-2 in endothelial cells. J Biol Chem 275: 11058-11063, 2000.

18 Kitchens RL and Thompson PA: Modulatory effects of sCD14 and LBP on LPS-host cell interactions. J Endotoxin Res 11: 225229, 2005.

19 Yang R, Murillo FM, Delannoy MJ, Blosser RL, Yutzy WH, Uematsu S, Takeda K, Akira S, Viscidi RP and Roden RBS: B lymphocyte activation by human papillomvirus-like particles directly induces Ig class switch recombination via TLR4MyD88. J Immunol 174: 7912-7919, 2005.

20 Clifford G, Franceschi S, Diaz M, Munoz N and Villa LL: HPV type-distribution in women with and without cervical neoplastic diseases. Vaccine 24: S26-34, 2006.

21 Schiffman M, Herero R, Desalle R, Hildesheim A, Wacholder S, Rodrigez AC, Bartti MC, Sherman ME, Morales J, Guillen D, Alfaro M, Hutchinson M, Wright TC, Solomon D, Chen Z, Schussler J, Castle PE and Burk RD: The carcinogenecity of human papillomavirus types reflects viral evolution. Virology 337: 76-84, 2005. 
22 Yu L, Wang M, Li M, Zhong J, Wang Z and Chen S: Expression of toll-like receptor 4 is down- regulated during progression of cervical neoplasia. Cancer Immunol Immunother 59: 1021-1028, 2010.

23 Pannone G, Bufo P, Pace M, Lepore S, Russo GM, Rubini C, Franco R, Aquino G, Santoro A, Campisi G, Rodolico V, Bucci E, Ilardi G, Mascolo M, Merolla F, Lo Muzio L, Natalicchio I, Colella G, Trino S, Laurenzana I, Leonardi R and Bucci P: TLR4 down-regulation identifies high risk HPV infection and integration in head and neck squamous cell carcinomas. Front Biosci 8: 15-28, 2016.

24 Levi JE, Rahal P, Sarkis AS and Villa L: Human papillomavirus DNA and p53 status in penile carcinomas. Int J Cancer 76: 779 $783,1998$.
25 Bethune G, Campbell J, Rocker A, Bell D, Rendon R and Merrimen $\mathrm{J}$ : Clinical and pathologic factors of prognostic significance in penile squamous cell carcinoma in a North American population. Urology 79: 1092-1097, 2012.

Received August 9, 2017

Revised August 24, 2017

Accepted August 28, 2017 